\title{
Spirituality and religiousity in the experience of suffering, guilt, and death of the elderly with cancer
}

\author{
Espiritualidade e religiosidade no vivido do sofrimento, culpa e morte da pessoa idosa com câncer
}

Espiritualidad y religiosidad en la experiencia del sufrimiento, culpabilidad y muerte del anciano con câncer

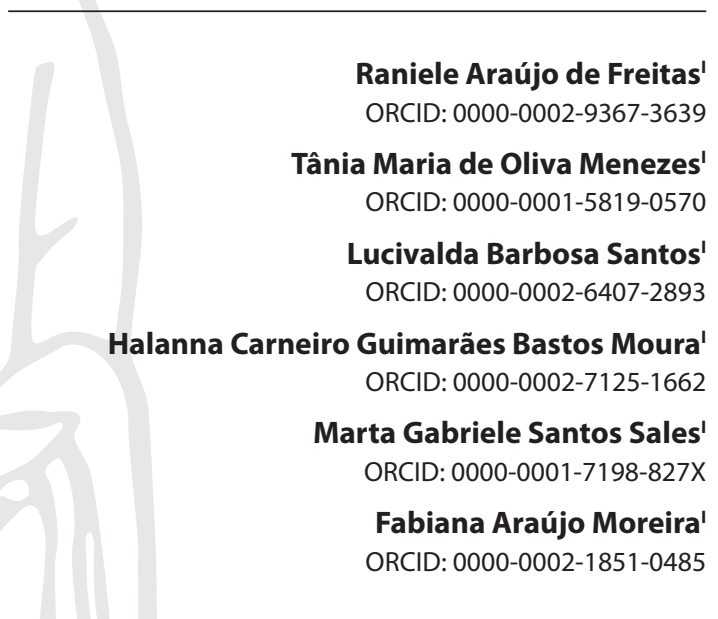

'Universidade Federal da Bahia. Salvador, Bahia, Brazil.

How to cite this article: Freitas RA, Menezes TMO, Santos LB, Moura HCGB, Sales MGS, Moreira FA. Spirituality and religiousity in the experience of suffering, guilt, and death of the elderly with cancer. Rev Bras Enferm. 2020;73(Suppl 3):e20190034. doi: http://dx.doi.org/10.1590/0034-7167-2019-0034

Corresponding author:

Raniele Araújo de Freitas E-mail: ranifreitas84@gmail.com

EDITOR IN CHIEF: Dulce Barbosa ASSOCIATE EDITOR: Margarida Vieira

Submission: 02-12-2019

Approval: 08-07-2019

\section{ABSTRACT}

Objective: to understand spirituality and religiosity in the experience of suffering, guilt, and death of the elderly with cancer. Method: qualitative research based on Viktor Frankl's Existential Analysis. Twenty phenomenological interviews were conducted with people over 60 years old undergoing chemotherapy treatment at an oncology unit of a hospital in the city of Salvador, Bahia State, Brazil, between August and October 2018. Results: the following categories emerged: Experiences spirituality and religiosity in the face of the tragic triad and existential emptiness; Uses spirituality/religiosity as resilience strategies. After apprehension of ontic aspects, it was possible the ontological understanding of spirituality and religiosity in the face of suffering, guilt, and death experienced in the elderly with cancer's daily life. Final considerations: spirituality and religiosity were understood as coping strategies used in the unstable experience of the elderly with cancer, providing comfort and resilience.

Descriptors: Aged; Spirituality; Religion; Neoplasms; Nursing.

\section{RESUMO}

Objetivo: compreender a espiritualidade e a religiosidade na vivido do sofrimento, culpa e morte da pessoa idosa com câncer. Método: pesquisa qualitativa fundamentada na Análise Existencial de Viktor Frankl. Foram realizadas 20 entrevistas fenomenológicas com pessoas acima de 60 anos, submetidas a tratamento quimioterápico na Unidade de Oncologia de um hospital da cidade de Salvador, Bahia, Brasil, no período entre agosto e outubro de 2018. Resultados: desvelaram-se as seguintes categorias: Vivencia a espiritualidade e a religiosidade face à tríade trágica e a vazio existencial; Utiliza a espiritualidade e a religiosidade como estratégias de resiliência. Após apreensão dos aspectos ônticos, foi possível a compreensão ontológica da espiritualidade e da religiosidade diante do sofrimento, culpa e morte vivenciadas no cotidiano da pessoa idosa com câncer. Considerações finais: a espiritualidade e a religiosidade foram compreendidas como estratégias de enfrentamento utilizadas no vivido instável da pessoa idosa com câncer, proporcionando conforto e resiliência.

Descritores: Idoso; Espiritualidade; Religião; Neoplasias; Enfermagem.

\section{RESUMEN}

Objetivo: comprender la espiritualidad y la religiosidad en el sufrimiento, la culpa y la muerte de los ancianos con cáncer. Método: investigación cualitativa basada en el análisis existencial de Viktor Frankl. Se realizaron veinte entrevistas fenomenológicas con personas mayores de 60 años, sometidas a tratamiento de quimioterapia en la Unidad de Oncología de un hospital en la ciudad de Salvador, Bahía, Brasil, entre agosto y octubre de 2018. Resultados: se revelaron las siguientes categorías: Experimente la espiritualidad y la religiosidad frente a la tríada trágica y el vacío existencial; Utiliza la espiritualidad y la religiosidad como estrategias de resiliencia. Después de la comprensión de los aspectos ónticos, fue posible la comprensión ontológica de la espiritualidad y la religiosidad frente al sufrimiento, la culpa y la muerte experimentados en la vida cotidiana de los ancianos con cáncer. Consideraciones finales: la espiritualidad y la religiosidad se entendieron como estrategias de afrontamiento utilizadas en la experiencia inestable de las personas mayores con cáncer, que proporcionan comodidad y resistencia. Descriptores: Anciano; Espiritualidad; Religión; Neoplasias; Enfermería. 


\section{INTRODUCTION}

Changing the Brazilian demographic profile presents with increasing number of elderly. Aging is a natural process and suffers intrinsic and extrinsic influences represented by particular aspects of the life trajectory and collectivity ${ }^{(1)}$. Being an elderly is not just a chronological issue, since in elderly groups there are numerous differences in the way they perceive, feel and face this stage of life $\mathrm{e}^{(2)}$. There are people who age with good quality of life and health, with few pathologies, good levels of stress control and life satisfaction. In contrast, there are others who experience inactivity, comorbidities, and depressive symptoms that compromise the quality of life in old age.

With the increase in life expectancy and, consequently, the elderly population increase, chronic diseases became more present, being directly linked to aging and falling mortality ${ }^{(3)}$. In this sense, cancer stands out among the chronic diseases ${ }^{(4-5)}$.

Advancing age is a risk factor for cancer development; Among the most common in old age are prostate cancer, breast cancer, non-melanoma skin, colon and rectum cancer, lung cancer, stomach, and cervical cancer ${ }^{(6)}$. In Brazil, it is estimated that by 2030, the global cancer burden will be 21.4 million new cases and 13.2 million deaths as a result of population growth and aging ${ }^{(7)}$.

The elderly person sometimes already has other comorbidities, and when diagnosed with cancer, goes through modification of perceptions, as well as the imposition to live with a disease that carries a series of uncertainties and changes in existence. Organic changes arising from this new condition impose a new way of being in the world and relating to it. Moreover, cancer diagnosis carries with it stigmata that can have a devastating effect, that is, it refers to the idea of death, fear of mutilation and disfigurement, as well as implications related to the loss of productivity and physical abilities of people ${ }^{(8)}$.

Even though studies evolved on the subject and new therapeutic mechanisms, cancer is still a feared and stigmatized disease and, therefore causes a great biopsychosociospiritual maladjustment. Consequently, some older people find in spirituality, or in their beliefs, support to understand suffering, and identify strategies to deal with stressors and thoughts arising from the situation experienced ${ }^{(9)}$.

Religiosity and spirituality are important resources used to fight cancer worldwide, although they are little explored in different cultures $^{(10)}$. There was association between resilience, suffering, and spirituality, concluding that the spiritual dimension of people with cancer should be included in health interventions, since it seems to be related to higher existential growth, adaptation to the disease, functional well-being and quality of life $\mathrm{e}^{(11-12)}$.

Although the terms "religiosity" and "spirituality" are often used as synonyms and are closely related, they have different meanings. Religiosity involves a set of dogmatic beliefs, language, and practices that are grounded in an accumulated tradition with symbols, rituals, ceremonies, and explanations of life and death. However, spirituality is universal and not limited to religious practices; It involves personal and intimate values, constituting what drives life and, as such, promotes personal growth and resignification of lived and existential experiences, guiding the meaning of life ${ }^{(13)}$.
The tragic triad, anthropological characteristic manifestation, is composed of suffering, guilt, and death ${ }^{(14)}$. Faced with cancer, suffering, guilt and death permeate the elderly's experience, since there is a relationship between the person in the world with the existential tension of man, being between "being" and "must be". Furthermore, the more one feels meaningless in life, the greater the likelihood of existential emptiness ${ }^{(14)}$. For Viktor Frankl's Existential Analysis, the study's theoretical-philosophical framework, it is possible to transform suffering into human achievements and achievements, based on self-transcendence, that is, the spiritual dimension.

Spirituality is the most specific characteristic of man, and the spiritual dimension is composed of the existential and transcendental dimensions. Thus, spirituality and religiosity demarcate their role in the experience of human beings, as resilience strategies used in the face of adversity imposed by illness. They can resignify the meaning of life and awaken to optimistic and responsible attitudes in search of overcoming the existential emptiness installed ${ }^{(15)}$. Emptiness is described as a feeling that settles in the being, caused by the meaninglessness of life, leaving it in a deep boredom and with the feeling that life has no value ${ }^{(16)}$.

Therefore, goals that contemplate spirituality and religiosity may be set in the challenge of promoting the encounter and/or resignification of purpose of existence that imply the quality of life. Thus, it was outlined as a research question of the study: what is the meaning of spirituality and religiosity in the experience of suffering, guilt, and death of the elderly with cancer?

\section{OBJECTIVE}

To understand spirituality and religiosity in the experience of suffering, guilt, and death of the elderly with cancer.

\section{METHODS}

\section{Ethical aspects}

The study obeyed the Resolution 466/12 ethical precepts of the Brazilian National Health Board (Conselho Nacional de Saúde), which discusses the guidelines and rules that regulate research with human beings ${ }^{(17)}$. All participants who contributed to the research signed the Informed Consent Form, which informed about the risks and benefits, as well as the guarantee of anonymity and the possibility of withdrawal at any time during the interview, without causing any harm or loss. To ensure anonymity, participants were identified by the letter I, followed by an interview order number. The research is linked to the Elderly Studies and Research Center of the Nursing School of Universidade Federal da Bahia, being approved by the Research Ethics Committee.

\section{Type of study}

This is a phenomenological study based on the theoretical assumptions of Viktor Frankl's Existential Analysis, guided by the COREQ tool ${ }^{(18)}$. Phenomenology has been taken as an opportunity to describe how humans can understand themselves and how they interpret their existence, far from pre-established 
patterns within psychodynamic or socioeconomic hypotheses ${ }^{(15)}$. The article originated from the Master's dissertation entitled "Sentido da espiritualidade e da religiosidade no vivido da pessoa idosa com câncer".

\section{Study setting}

The study site was a reference philanthropic hospital in cancer care in the city of Salvador, Bahia. This hospital has a daily movement of more than $3,000,000$ visits in its outpatient clinics, and has full coverage by the Brazilian Unified Health System (Sistema Único de Saúde) in its work. This hospital performs an average of $3,200,000$ annual procedures ${ }^{(19)}$.

The hospital unit selected for the study was the Clinical Oncology, where medication is dispensed to patients followed and infusions of chemotherapy cycles. The choice of this unit was due to the care of many elderly people, and because they have scheduled return to the unit for compliance with chemotherapy sessions, allowing greater contact with researchers.

\section{Study participants}

Participants were 20 elderly people with cancer. The choice of these people was intentional and when they were in the unit for infusion of chemotherapy, or for dispensing oral medications.

Inclusion criteria were: 1 . Elderly people aged 60 years and over, considering it important to include information in different age groups; 2 . Ability to establish the verbal communication process, assessed through Mini-Mental State Examination (MMSE) application; 3. To be under oral or venous chemotherapy treatment; 4 . In cases of venous therapy, older people who are in the 2 nd session onwards. This inclusion was due to the fact that, in the first session, the elderly could be anxious or expecting the unknown; 5. To know the cancer disease diagnosis. Exclusion criteria: 1. Emotional or organic discomfort during information gathering, which would prevent message capture.

MMSE is characterized as a neuropsychological test that quickly, easily, and simply verifies the cognitive status of adult and elderly people ${ }^{(20)}$. Six elderly people eligible for the study were excluded: one, for refusing the approach dialogues; two, because they were not aware of the cancer diagnosis at the family's request; two, due to the impossibility of MMSE application due to advanced cognitive deficit (Alzheimer); and one, for presenting disconnected speech on the interview day.

As it is a phenomenological study, the number of participants was delimited when the meanings of the participants' statements began to show regularity, being sufficient to answer the goal set and unveil the investigated phenomenon ${ }^{(21)}$.

\section{Collection and organization of data}

The phenomenological interview was used as a technique to construct the information, which seeks, through a movement of understanding, to access the lived experience of the human being and to unveil the meanings and meanings of daily life ${ }^{(22)}$. What is rescued by participants during the open-ended dialogue is the speech already processed by them. This speech was structured based on what the phenomenon is for itself, that is, experiences that are codified and stored in the consciousness ${ }^{(23)}$.

The interviews took place between August and October 2018 in the Clinical Oncology unit, privately, which ensured information confidentiality. It is important to point out that a moment of setting was carried out prior to the beginning of interviews, which is characterized as a process of approaching the researcher with the research field, a fundamental step in phenomenological research.

A digital recorder was used to ensure reliable transcription and interpretation of information, as well as non-participant observation, to capture gestures, expressions and other elements of nonverbal communication. The time for response was free, and the researcher was completely available to participants.

\section{Data analysis}

After the interviews, the vague and mediated analysis of experiences was performed. Such a strategy does not consent to the immediate understanding of the elderly person with cancer. It was necessary to follow Giorgi's phenomenological-empirical model, adapted by Vietta ${ }^{(24)}$, being justified by the phenomenological mode that studies the experience with conscious experience, in which the researcher takes a deep dive into the collected speeches and strives to capture, discern and unveil what is specific in each experience, in order to understand the proposed phenomenon.

Thus, the phenomenological analysis went through six steps: 1. Understanding the meaning of speech within the global structure; 2 . Rereading the text, as many times as necessary, in order to identify units of meaning understood here as effect phrases. These revealed, in the verbal content expressed by participants, significant aspects of their perceptions, for understanding and analysis of their experiences; 3 . Identification and classification of aspects that present content convergences, looking for what was constant in the lines of each; 4. Grouping of the phrases or their meanings into subcategories which were then regrouped by comparison between speech contents, constructing the empirical categories that make up the phenomenon structure; 5 . Presentation of these groupings in representative tables, for a better results visualization ; 6 . Comprehensive analysis of the significant data of these groupings ${ }^{(24)}$, based on the interpretation of the content in the light of Viktor Emil Frankl's theoretical framework.

\section{RESULTS}

\section{Characterization of study participants}

Of the 20 study participants, 13 are female and seven male. The average age was 71.4 years old, ranging from 61 to 89 years old, with five very elderly. As for the marital status of participants, 11 are married, seven widowers and two are single. As for religion, 12 participants are Catholic; four are Protestant; two have no religion; one is Jehovah's witness; and one follows Umbanda (Umbanda is a Brazilian religion that blends African religions with Catholicism, Spiritism, and considerable indigenous lore). There was a range from two months to eight years of cancer diagnosis. As for education, in general, participants did not study or studied a few years, and five are illiterate. Only one older person had completed higher education. 
The thorough and exhaustive reading of experiences shared by study participants, added to the perception about the contexts that surround them, enabled the elaboration of categories, with meaning units extracted from the speeches, to understand the meaning of spirituality and religiosity in the face of suffering, guilt and death in the lives of the elderly with cancer. In this process, the elderly person with cancer has unveiled himself as a being who:

\section{Experiences spirituality and religiosity in the face of tragic triad and existential emptiness}

Awareness of the diagnosis of cancer, together with the inability to perform daily tasks and the adverse reactions presented to chemotherapy drugs, reveal the existential emptiness, keeping the elderly with cancer in the dark view of life. Issues related to suffering were unveiled by participants and, in those moments, calling for divinity, having confidence in the support of something greater, sacred and transcendent was manifested, as the following statements:

I remember getting cancer every day. I believe in faith in God and I keep pushing forward. (I3, woman, Catholic, 74 years)

All my life I've worked, and now I'm not working. That's it, I see others working and I don't work. This disease is terrible. It takes us a lot of faith to win. (14, woman, Catholic, 69 years)

14 corroborates with I3, claiming to use faith in God to continue life. The following reports bring suffering in an intense, corrosive, and painful way:

The worst thing is that you live on top of suffering. I feel sad, anguished, we feel humiliated, don't we? I don't feel happy no. I ask God to have mercy. (15, woman, Catholic, 65 years)

After chemotherapy, I get a bad body, everything hurts, even my nail hurts, my hands, my body, and I can't sleep. I feel dizzy, want to throw up, take it day and night with it. It's three days like this. (I8, woman, Catholic, 73 years)

It makes you want to disappear from the world, but then I ask God for strength. During the day I stay alone in bed because my legs hurt and I feel like throwing up. I feel blue, I don't want anything. I'm suffering too much: it's agony, lack of sleep, and when I'm taking it here [chemotherapy] I get tremendous, the pressure gets high and, gives a lot of agony. (I15, woman, Evangelical, 63 years)

Pain is reflected in 15 by the emphatic form that describes feeling distressed and humiliated by the inconvenience brought on by cancer, asking God for mercy.

$I 8$ and I15 suffer daily discomfort due to the side effects of chemotherapy (mild to limiting symptoms) that impair the activities that were normally performed, leaving them in passive condition.

With the challenges of everyday life, thoughts evoked by participants also turn to guilt. In this context, the feeling of guilt is based on the diagnosis of cancer, and point out lifestyle habits, carelessness and non-compliance with medical guidelines, as the reason for the disease, as reported below:

The disease came by my facilitation. The doctor told me that I could not gain weight or sunbathe. I left the office and paid all the sun on the street selling. It's over me, it was my stubbornness, lack of patience to stay still. (16, man, Catholic, 70 years)

I could have taken better care The disease was my fault, all my fault, I didn't go to a doctor right away. (I12, man, no religion, 64 years)

16 reports the insistence on situations that left him exposed and blames himself for the negative event, understanding cancer as a return. 112 experiences the illness process as a punishment for not taking care of his health.

The diagnosis and experience with cancer have a profound impact on the life of the elderly, and can be experienced as a synonym of death. Facing the disease is now understood as a struggle between life and death. If finitude was poorly reflected, then the being-in-the-world develops awareness of it, and the thought of death and dying moves daily, as the following lines state:

I don't sleep, I stay up all night, I think I'm going to die, I think of my children and grandson. (19, woman, Catholic, 62 years)

With this disease, I ask God so much not to die. I try not to think I'm going to die. If I have this disease, I have to conform and trust in God's healing. (113, woman, Catholic, 71 years)

I'm afraid! IIIness is something that can take my life. Have you thought about it? That's why I come to treatment, I cling to faith in God not to give up. I also think how it will be there in the other world after death, we never lived there! (114, woman, Catholic, 66 years)

19 has his sleep impaired by thoughts related to the possibility of death from the disease. 113 tries not to think about this possibility and prefers to give confidence in God's healing.

114 believes that to die is to be absent from this world, implying one's entry into an unfamiliar one. Faced with the fear of the unknown, he also turns to God for help in following his life. Thoughts like this show that spirituality and faith demarcate territory in living with cancer, emerging spiritual beliefs/convictions about the passage from the material world to the spiritual world.

At first, when I learned of the disease, I thought I was going to die. I had a client, she came up with a lump in her breast because she died. Then I freaked out. I said, ok, I'm going to die too! I'm terrified of death (raised his voice and cried). I don't even care about death. I do not want to! (I10, woman, from Umbanda, 65 years)

The statement above states that, when diagnosed, I10 thought that he would die immediately, especially with the death of an acquaintance, due to a health problem similar to his own. At the same time, he reveals his dread of death, with weeping and raised tone of voice, and:

\section{Uses spirituality and religiosity as daily resilience strategies}

Spirituality and religiosity were unveiled as strategies used by participants to experience the challenges, discomforts, sufferings and uncertainties of the disease process. The strength acquired by spirituality is recognized to face adverse situations of life, from the connection with the Sacred and the Transcendent. In the speeches below, it is observed that faith reflects the search for 
the meaning of life of those who experience cancer and thinks about healing:

I have faith, I ask God a lot. I believe in faith in God and I keep pushing. (12, man, Catholic, 61 years)

It has been confident because I seek God a lot and he has given me a lot of strength, a lot of faith and through many prayers and my children, relatives and friends have helped me a lot in this day to day life. (17, woman, Evangelical, 75 years)

Everything I do goes forward, because I have faith in God. (I16, man, Catholic, 83 years)

Faith has no end, it is hope that does not end. I feel that emotion in my heart and I vent. (I18, man, Evangelical, 80 years)

In addition to belief in God and sacred entities, religion/religiosity can motivate, influence behavior and comfort the elderly with cancer, reflecting the importance in the lives of these beings:

When I feel anything about chemotherapy, I close my little eye, start asking my God. When I think not, the way it came, it's gone. (I1, woman, Evangelical, 64 years)

I ask, I pray a lot, the prayer that Jesus left, the Our Father, I believe in God the Father, the Hail Queen. (13, woman, Catholic, 74 years)

I say my prayers when I wake up at noon and when I go to sleep. I read the bible. (I20, man, no religion, 84 years)

I only ask in faith, the saints, the Orishas, all of them! I have this faith and I take care of the saints. I light a candle, I pray. Cultivation! (I10, woman, from Umbanda, 65 years)

Power of faith manifestation is felt by 11 , because when closing his eyes and dialoguing with God, he feels the improvement of symptoms arising from antineoplastic therapy. 13 reports that he likes to pray and performs the specific liturgies of his belief. 110 brings that cultivates your faith in the Orisha (an Orisha (also spelled Orisa or Orixa) is a spirit or deity that reflects one of the manifestations of God in the Yoruba spiritual or religious system).

Although the number of participants attending religious institutions is smaller, going to mass or worship becomes relevant to them, bringing them well-being, as evidenced in the following statements:

I congregate, I go to my church. There is worship Saturday and Monday, I just don't go on chemotherapy day and a few days later, because I get bad. (I18, man, Evangelical, 80 years)

I attend my congregation. I go twice a week, on Wednesday and Saturdays. (I19, woman, Jeovah's Witness, 82 years)

Some participants point out the impossibility of going to religious institutions, either due to the incapacity of aging or signs and symptoms resulting from chemotherapy treatment, but they seek ways to be practicing their faith, according to the statements below:

Lately I go more [to church] on Sunday early. After chemotherapy, I cannot sunbathe, nor can I be cold, so I go more on Sunday morning, I go to Sunday school, I go to the holy supper. This is all too important to me. (I1, woman, Evangelical, 64 years)

I went to mass a lot; I didn't miss a Sunday. I'm not going to church lately, but I hear mass on the radio. I'm not going because there's no one to take me, I can't see anymore. But now there is a catechist who will bring me the "Body of Christ", Saturday, for me to make communion with Christ. (117, Man, Catholic, 89 years)

11 reports that he goes to church early in the morning, because he should not be exposed to the sun or the cold, because of the increase in thermal sensitivity, which brings discomfort. Still, he comments on the importance of his participation in periodic church activities he attends. In addition to changes in religious practices, I17 says that given her inability to attend church, a catechist goes to her residence once a week to bring the Host representing the Body of Christ. Therefore, it shows the importance that being in communion with God represents in their lives.

\section{DISCUSSION}

The sense of spirituality and religiosity in the daily life of the elderly person with cancer who lives suffering, guilt and death was unveiled from vague and median analysis of statements, reaching an ontological understanding.

The human being is seen within a concentric dimensional structure. The somatic and the psychic are grouped around a core, the spiritual. These dimensions are articulated, but in the sense of existential ontology, they are subdivided into existence and facticity spheres. In facticity, the human being has the somatic and psychic dimensions. In existence sphere, it is permeated by the noetic, the spiritual ${ }^{(25)}$.

Participants allowed to unveil the experience in the existential sphere with suffering, guilt and death, named by Frankl as a tragic triad. Suffering is inevitable in people's lives, and it is impossible not to have freedom to face it, since human beings need tension to give a new meaning to their existence. The non-responsible positioning in the face of suffering causes the being to be lost, drifting and nonconformed ${ }^{(14)}$, but it is necessary to look at the suffering ${ }^{(15)}$.

Guilt turned out to be the distance between 'who I am' and 'who I could be'. For participants, while considering not choosing, they cannot eliminate guilt. It is proper for a human being to feel guilty, for he has a conscience and is guided by values. When you feel that you have done something wrong or failed to do what should be done, you feel guilty and responsible for it ${ }^{(26)}$.

The person who has not realized the possibilities of senses (should-be), or recognizes that he has done little of the possibilities and values that life has provided him, somehow leaves a gap in his existence, which could arouse ontological guilt ${ }^{(16)}$. When guilt is present in speeches of participants, it comes from not carrying out their health care when younger, or even after some medical recommendation.

Still in the tragic triad, although they know that death is part of transience of life, participants become aware of finitude when experiencing cancer and chemotherapy treatment. Transience is a problem that afflicts the person with an incurable disease, which confronts not only suffering and guilt, but also imminent death ${ }^{(27)}$. Speeches unveiled the relationship of cancer with death, which frightens many issues, including the lack of knowledge about afterlife. 
Although participants remain involved in suffering, sometimes not adhering to conscious attitudes towards the tragic triad experienced, it was possible to understand that spirituality and religiosity are present in the challenging daily life, resorting to God and their beliefs in times of distress and despair. The search for the Sacred and the access to spirituality occur daily as attempts to confront the existential emptiness installed.

Individual prayers, specific prayers, bible reading, and going to religious temple were expressed as strategies for resilience and daily coping. Some participants pray daily and address religious institutions for the importance of faith in the face of adversity in living with cancer.

Existential analysis does not seek proof of the existence of God, but describes the experience of the religious man. Given that, for the religious man, the absolute remains in transcendence, symbolization becomes necessary, in which the relationship between the image and the symbolized being is a human phenomenon, specific to the religious being ${ }^{(16)}$. Holding specific liturgies and prayers with reference to images and symbols of their religions reinforces the participants' experience of faith, making them beings-with religiosity in search of a new meaning to life. Participants, through their religious practices, find support to cope with challenging situations, leaving them more comforted.

The human being would not move a finger and would not even breathe if in the deepest base of his existence, in the innermost being, he had no primary confidence in the ultimate sense. Thus, trust in meaning and faith in the greater being, however hidden, are transcendental and indispensable ${ }^{(15)}$.

The religious man is the man of higher hearing than the irreligious. The religious man is able to assume his life as a mission to be fulfilled, living this mission as a search for the encounter with this instance, being able to complete the ontological dynamic. In the religious person, when the spiritual dimension is accessed, allowing to be led by You and oriented in the dynamics of one's own consciousness, the responsible being and the conscious being occur simultaneously ${ }^{(16)}$.

The relationship of spirituality and religiosity depth unveiled in the participants' experience with suffering, guilt and death reflects the intimacy between the Self and a Transcendent (the Sacred) in various spiritual ways. Among them are through the deep monologue of the human being with his own conscience, God being his intimate partner, through religious rites and symbols that express a given spiritual language, from sensible experiences of life $\mathrm{l}^{(25)}$.

\section{Study limitations}

Limitation of this study is related to the non-generalization of its results to the entire elderly population with cancer, since it refers to a group of elderly people with cancer in a certain location in Bahia State. However, the results allow a deep discussion of the information understood and can be applied to elderly people who experience similar situations to the research participants.

\section{Contributions to nursing}

The study results contribute to reflections on the need for nurses to act in the spiritual dimension of the elderly in many settings. Moreover, these reflections arouse that not only biological and technical aspects are aimed at health care, but that spiritual aspects can be inserted into clinical practice. These reflections may encourage the insertion of spirituality and religiosity needs in the Systematization of Nursing Care. Therefore, educational institutions will be able to broaden the perspective on gerontology, focusing on health professionals training that contemplate the totality of the being.

\section{FINAL CONSIDERATIONS}

Spirituality and religiosity were revealed as important coping strategies used by the elderly with cancer in the face of suffering, guilt, and thoughts about death that permeate the unstable daily life. These resources are able to provide relief in difficult times, strength to overcome emotional impacts, and can help in wellbeing pursuit and meaning of life resignification, in the face of what cannot be changed.

\section{REFERENCES}

1. Garbaccio JL, Tonaco TAB, Estêvão WG, Barcelos BJ. Aging and quality of life of elderly people in rural áreas. Rev Bras Enferm [Internet]. 2018 [cited 2019 Jan 16];71(Suppl 2):724-32. Available from: http://www.scielo.br/pdf/reben/v71s2/0034-7167-reben-71-s2-0724.pdf

2. Chaves LJ, Gil CA. Older people's concepts of spirituality, related to aging and quality of life. Ciênc Saúde Colet [Internet]. 2015 [cited 2019 Jan 15];20(12):3641-52. Available from: https://www.scielo.br/pdf/csc/v20n12/en_1413-8123-csc-20-12-3641.pdf

3. Oliveira PF, Queluz FNFR. A Espiritualidade no Enfrentamento do Câncer. Rev Psic IMED [Internet]. 2016 [cited 2019 Jan 13];8(2):142-55. Available from: https://seer.imed.edu.br/index.php/revistapsico/article/view/1314/1036

4. Mendes TR, Boaventura RP, Castro MC, Mendonça MAO. Occurrence of pain in cancer patients in palliative care. Acta Paul Enferm [Internet]. 2014 [cited from Jan 10];27(4):356-61. Available from: http://www.scielo.br/pdf/ape/v27n4/en_1982-0194-ape-027-004-0356.pdf

5. Freire MEM, Costa SFG, Lima RAG, Sawada NO. Health-related quality of life of patients with cancer in palliative care. Texto Contexto Enferm [Internet]. 2018 [cited 2019 Jan 16];27(2):1-13. Available from: http://www.scielo.br/pdf/tce/v27n2/en_0104-0707-tce-27-02-e5420016.pdf

6. Instituto Nacional do Câncer José Alencar Gomes da Silva (BR). Estimativa 2016: Incidência de câncer no Brasil [Internet]. Coordenação de Prevenção e Vigilância. Rio de Janeiro (RJ): INCA; 2014 [cited 2018 Mar 02]. Available from: http://www.inca.gov.br/estimativa/2016/estimativa2016-v11.pdf 
7. Instituto Nacional do Câncer José Alencar Gomes da Silva (BR). Estimativa 2018: incidência de câncer no Brasil [Internet]. Coordenação de Prevenção e Vigilância. Rio de Janeiro (RJ): INCA; 2017 [cited 2018 Mar 02]. Available from: http://www.inca.gov.br/estimativa/2018/estimativa-2018.pdf

8. Jonas LT, Silva NM, Paula JM, Marques S, Kusumota L. Comunicação do diagnóstico de câncer à pessoa idosa. Rev Rene [Internet]. 2015 [cited 2018 Jan 16];16(2):275-83. Available from: http://periodicos.ufc.br/rene/article/view/2726/2110

9. Nery BLS, Cruz KCT, Faustino AM, Santos CTB. Vulnerabilities, depression, and religiosity in the elderly hospitalised in an emergency unit. Rev Gaúcha Enferm. 2018;39:e2017-0184. doi: 10.1590/1983-1447.2018.2017-0184

10. Nejat N, Whitehead L, Crowe M. The use of spirituality and religiosity in coping with colorectal cancer. Contemp Nurse [Internet]. 2017 [cited 2019 Apr 24];53(1):48-59. doi: 10.1080/10376178.2016.1276401

11. Cheng Q, Liu X, Li X, Wang Y, Mao T, Chen Y. Improving spiritual well-being among cancer patients: implications for clinical care. Support Care Cancer [Internet]. 2019 [cited 2019 Apr 25];27(1):1-7. doi: 10.1007/s00520-019-4636-4

12. Paredes AC, Pereira MG. Spirituality, distress and posttraumatic growth in breast cancer patients. J Relig Health. 2017;57(5):1606-17. doi: 10.1007/s10943-017-0452-7

13. Sampaio AD, Siqueira HCH. Influência da Espiritualidade no Tratamento do Usuário Oncológico: Olhar da Enfermagem. Ensaios Cienc Cienc Biol Agrar Saúde [Internet]. 2016 [cited 2019 Jan 14];20(3):151-8. Available from: https://www.redalyc.org/pdf/260/26049965006.pdf

14. FrankI VF. O sofrimento de uma vida sem sentido: caminhos para encontrar a razão de viver. São Paulo (SP): É realizações. 1 ed. 2015. p. 128.

15. FrankI VF. Em busca e sentido: um psicólogo no campo de concentração. 40 ed. São Leopoldo (SP): Sinodal; Petrópolis (RJ): Vozes. 2016. p. 184.

16. FrankI VF. Um sentido para a vida: psicoterapia e humanismo. Aparecida (SP): Ideias e Letras. 21 ed. 2017. p. 176.

17. Conselho Nacional de Saúde (BR). Resolução no 466 de 12 de dezembro de 2012. Aprova as diretrizes e normas regulamentadoras de pesquisas envolvendo seres humanos [Internet]. Conselho Nacional de Saúde. Brasília, 2012 [cited 2019 Jan 14]. Available from: http:// conselho.saude.gov.br/ráspolis/2012/Reso466.pdf

18. Tong A, Sainsbury P, Craig J. Consolidated criteria for reporting qualitative research (COREQ): a 32-item checklist for interviews and focus groups. Int J Qual Health Care [Internet]. 2007[cited 2019 Jan 15];19(6):349-57. Available from: https://academic.oup.com/intqhc/ article/19/6/349/1791966

19. Liga Baiana Contra o Câncer (BR) Hospital Aristides Maltez: Histórico Institucional [Internet]. Salvador (BA): LBCC; 2018 [cited 2018 Jan 08]. Available from: http://www.lbcc.org.br/hospital.php

20. Melo DM, Barbosa AJG. O uso do mini exame do estado mental em pesquisas com idosos no Brasil: uma revisão sistemática. Ciênc Saúde Coletiva [Internet]. 2015 [cited 2018 Sep 20];20(12):3865-76. Available from: http://www.scielo.br/pdf/csc/v20n12/1413-8123-csc-20-12-3865.pdf

21. Reis CCA, Sena ELS, Menezes TMO. Experiences of family caregivers of hospitalized elderlies and the experience of intercorporeality. Esc Anna Nery[Internet]. 2016 [cited 2019 Jan 15];20(3):1-6. Available from: http://www.scielo.br/pdf/ean/v20n3/en_1414-8145ean-20-03-20160070.pdf

22. Moreira RCR, Lopes RLM, Santos NA. Entrevista fenomenológica: peculiaridades para la producción científica en enfermería. Index Enferm [Internet]. 2013 [cited 2018 Sep 20];22(1-2):107-10. doi: 10.4321/S1132-12962013000100024

23. Guerrero-Castañeda RF, Menezes TMO, Ojeda-Vargas MG. Características de la entrevista fenomenológica en investigación en enfermería. Rev. Gaúcha Enferm [Internet]. 2017 [cited Sep 20];38(2):1-5. Available from: http://www.scielo.br/pdf/rgenf/v38n2/0102-6933rgenf-1983-144720170267458.pdf

24. Vietta EP. Configuração triádica, humanista-existencial-personalista: uma abordagem teórica-metodológica de aplicação nas pesquisas de enfermagem psiquiátrica e saúde mental. Rev Latino-Am Enferm [Internet]. 1995 [cited 2019 Jan 15];3(1):31-43. Available from: http://www. scielo.br/pdf/rlae/v3n1/v3n1a04.pdf

25. FrankI VF. Logoterapia e análise existencial: textos de seis décadas. São Paulo (SP): Forense Universitária. 2014. p. 338.

26. Pereira GA, Aquino TAA. A culpa e suas relações com a religiosidade e o sentido da vida. Rev Logos Existência [Internet]. 2016 [cited Jan 10];5:(2):204-19. Available from: http://www.periodicos.ufpb.br/ojs/index.php/le/article/view/31974/16886

27. FrankI VF. A vontade de sentido: fundamentos e aplicações da logoterapia. São Paulo (SP): Paulus; 2016. p. 224. 